Check for updates

London, UK

Cite this as: $B M J 2021 ; 373: n 1186$ http://dx.doi.org/10.1136/bmj.n1186 Published: 10 May 2021

\title{
Covid-19: Don't abandon mask wearing in schools, say health experts
}

\section{Matthew Limb}

Covid rules in England requiring secondary school pupils to wear face coverings in classrooms could be dropped from mid-May, despite warnings from health experts and teaching unions.

Education secretary Gavin Williamson last week said that the requirement would be relaxed no sooner than 17 May, as part of the third stage of the "roadmap" out of lockdown. This is expected to be confirmed on 10 May by Prime Minister Boris Johnson, alongside easing of other controls.

But leading scientists have warned that guidance on masks should remain in place for longer and called for more transparency surrounding infections data. They cited signs of an increase of infections in schools that are forcing some to close and the spread of troubling new virus variants linked to schools.

Deepti Gurdasani, a clinical epidemiologist and senior lecturer in machine learning at Queen Mary University of London, said on 7 May, "B.1.617.2 [the variant first identified in India] has been spreading in secondary schools, yet the government has decided to remove masks from secondaries. If the government is following the data they should be happy to make this public."

Williamson told the Telegraph that removing face masks would "hugely improve" interactions between teachers and students, while all other safety measures will remain in place to help keep covid-19 out of classrooms. He said that the government guidance would continue to recommend mask wearing in school corridors and other areas where social distancing was not possible.

But a group of scientists, public health experts, and unions, including some members of Independent Sage, sent an open letter to Williamson on 4 May calling for face coverings to be worn in classrooms until at least 21 June. $^{1}$

The letter said, "To strip these necessary covid protections, when there are already too few mitigation measures in schools and when rates of covid-19 are still significant, would have consequences for the health of our children and their parents as well as their communities."

It said that the progress of the UK vaccination programme was not yet sufficient to fully mitigate the impact of transmission among children on infection rates in the community.

"Countries like Israel fully emerged from lockdown after fully vaccinating more than $80 \%$ of adults, and only re-opened schools fully in the last few weeks, with mitigations still in place, including mask mandates in classrooms," the letter said.

Signatories to the letter include Gurdasani; Martin McKee, professor of European public health at
London School of Hygiene and Tropical Medicine; and Christina Pagel, professor of operational research at University College London.

Figures published by the Office for National Statistics last week showed school infection rates between 15 and 31 March 2021-shortly after schools in England reopened following the third lockdown-were lower among staff and pupils in secondary schools compared with results from an earlier round of sampling in November and December 2020. ${ }^{2}$ Public Health England said the findings were "reassuring" and part of wider evidence that the risks of covid transmission in schools was low.

But there are concerns this overlooks more recent escalation and spread of covid infection in schools. In their letter, the group of experts said that by the start of the Easter break, prevalence of infection was "higher in school age children than in any other group."

Gurdasani last week highlighted several recent and large outbreaks in schools that had led to "significant disruption and closures" and the spread in the UK of the new variant, B.1.617.2, that had been "linked to secondary schools."

Paul Whiteman, general secretary of the school leaders' union National Association of Head Teachers, said, "Parents, pupils, and staff will want to understand why removing the requirement for face coverings in classrooms is considered appropriate when it is not for other enclosed spaces. We expect that school leaders will continue to work closely with their staff and communities and make decisions based on their risk assessments and local circumstances.”

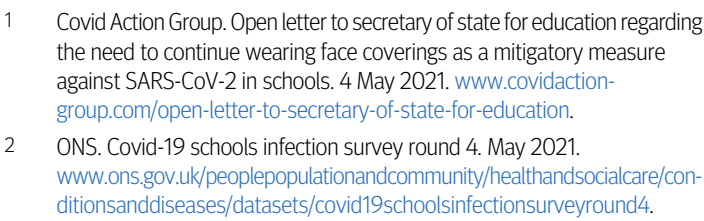

1 Covid Action Group. Open letter to secretary of state for education regarding the need to continue wearing face coverings as a mitigatory measure against SARS-CoV-2 in schools. 4 May 2021. www.covidactiongroup.com/open-letter-to-secretary-of-state-for-education.

2 ONS. Covid-19 schools infection survey round 4. May 2021. www.ons.gov.uk/peoplepopulationandcommunity/healthandsocialcare/conditionsanddiseases/datasets/covid19schoolsinfectionsurveyround4.

This article is made freely available for use in accordance with BMJ's website terms and conditions for the duration of the covid-19 pandemic or until otherwise determined by BMJ. You may use, download and print the article for any lawful, non-commercial purpose (including text and data mining) provided that all copyright notices and trade marks are retained. 